\title{
NEIL1 wt Allele
}

National Cancer Institute

\section{Source}

National Cancer Institute. NEIL1 wt Allele. NCI Thesaurus. Code C124096.

Human NEIL1 wild-type allele is located in the vicinity of 15q24.2 and is approximately 10 $\mathrm{kb}$ in length. This allele, which encodes endonuclease 8-like 1 protein, is involved in the repair of damaged or mismatched DNA. 